\title{
Sistem Penghantaran Obat Berbasis Biopolimer Kitosan pada Formulasi Film Forming System
}

\author{
Fajra Dinda Crendhuty*, Sriwidodo, Yoga WindhuWardhana
}

\begin{abstract}
Fakultas Farmasi Universitas Padjadjaran, Jalan Raya Bandung Sumedang Km. 21 Jatinangor 45363
*E-mail: fajra16001@mail.unpad.ac.id
\end{abstract}

(Submit 18/5/2020, Revisi 27/5/2020, Diterima 03/8/2020, Terbit 29/10/2020)

\begin{abstract}
Abstrak
Sistem penghantaran obat topikal melalui film forming system mampu mengatasi keterbatasan sediaan konvensional dengan membentuk film tipis in situ dan memberikan kontak lebih lama dikulit yang dapat mengontrol pelapasan obat. Polimer kitosan sebagai basis film forming system banyak digunakan karena sifatnya yang mukoadhesif dan mampu membentuk film tipis. Dalam review ini, dibahas penggunaan kitosan sebagai basis dalam sistem penghantaran obat yang telah banyak diaplikasikan dengan berbagai aktivitas biologis. Dalam formula FFS, perlu diperhatikan parameter kritis yang mempengaruhi formulasi film forming system seperti pemilihan konsentrasi polimer, kombinasi dengan polimer lain seperti polimer sintetik polyvinyl alcohol (PVA), derajat deasetilasi kitosan yang rendah untuk meningkatkan sifat mekanik dan pembentukan film yang lebih baik, penambahan eksipien seperti plasticizer, humektan dan crosslinker yang dilaporkan berpengaruh terhadap sifat fisika kimia obat. Parameter fisikokimia yang diinginkan harus memiliki sifat mekanik yang mampu mengatasi tekanan takensial gerakan tubuh, $\mathrm{pH}$ untuk formula topikal berada pada rentang $4-6$, waktu pembentukan film kurang dari 15 menit serta water vapour permeability (WVP) lebih dari 0,05 $\mathrm{g} / \mathrm{cm}^{2}$. 24 jam. Dari berbagai hasil penelitian, dilaporkan bahwa film forming system menggunakan basis kitosan menjadi salah satu pendekatan yang potensial dalam sistem penghantaran obat untuk meningkatkan efektivitas permeasi dan penetrasi yang lebih baik.
\end{abstract}

Kata kunci: biopolimer, film forming system dan kitosan.

\section{Pendahuluan}

Drug Delivery System (DDS) didefinisikan sebagai formulasi atau sistem yang mampu memediasi penghantaran zat terapeutik dalam tubuh untuk meningkatkan efek terapi, mengurangi efek samping obat, meningkatkan bioavaibilitas serta meningkatkan kepatuhan pasien.[1] Proses ini meliputi pemberian produk terapeutik, pelepasan bahan aktif oleh produk, dan pengangkutan selanjutnya bahan aktif melintasi membran biologis ke lokasi kerja. ${ }^{[1,2]}$ Berdasarkan rute dan target terapi, sistem penghantaran obat terbagi atas beberapa macam antara lain Gastrointestinal Drug Delivery System, Transmucosal Drug Delivery System, Nasal Drug Delivery System, Colorectal Drug Delivery System, Pulmonary Drug Delivery System, Cardiovascular Drug Delivery System dan Transdermal Drug Delivery System. ${ }^{[2]}$ 
Pemberian obat secara topikal atau Transdermal Drug Delivery System dapat menghindari first pass metabolism, mudah digunakan dan memberikan rasa nyaman pada pasien, luas permukaan yang besar serta absorpsinya yang besar sehingga dapat memberikan penghantaran topikal maupun sistemik. Pemberian secara topikal harus dalam bentuk sediaan. Sediaan konvensional memiliki keterbatasan seperti rasa lengket dan rasa tidak nyaman, waktu kontak yang singkat, serta dapat menyebabkan iritasi pada kulit. ${ }^{[3]}$ Keterbatasan ini, dapat diatasi dengan sistem penghantaran Film Forming System.

Film Forming System (FFS) adalah sediaan yang sering digunakan dalam industri makanan atau obat-obatan. Sistem ini merupakan sediaan non solid yang menghasilkan film in situ setelah diaplikasikan pada kulit atau permukaan tubuh lainnya. ${ }^{4]}$ Pembentukan film yang fleksibel dan jernih pada kulit setelah penguapan pelarut, dapat diformulasikan menggunakan polimer seperti cellulose derivative, polyvinyl pyrolidone (PVP), polyvinyil alcohol (PVA), polymethacrylates dan chitosan. ${ }^{[5]}$

Kitosan merupakan polisakarida alami yang berasal dari kitin, bersifat biokampatibel, aktivitas biologis yang spesifik, [6] imunogenesitas dan toksisitas yang sangat rendah. Kepadatan muatan positif yang tinggi memberikan sifat mukoadhesif, membuat kitosan menjadi polimer yang ideal untuk penghantaran obat pada jaringan mukosa. ${ }^{[7]}$ Kitosan pun dapat membantu penyembuhan jaringan, dan berinteraksi baik dengan sel manusia. ${ }^{[8]}$

Beberapa formula kitosan dengan eksipien tambahan yang telah dilakukan pada penelitian-penelitian sebelumnya, menunjukkan keberhasilan dalam penghantaran obat seperti permeasi dan penetrasi yang lebih tinggi pada kulit. ${ }^{[9]}$ Keberhasilan ini diamati melalui parameter fisikokimia seperti viskositas, ${ }^{[10,11,12]} \mathrm{pH}$ solution, $\left.{ }^{[12,13} 14,15,16\right]$ drying time, ${ }^{[17,18]}$ hardness, adhesiveness, stickness, ${ }^{119,20)}$ cosmetic appearance, ${ }^{[21]}$ particle size analysis, ${ }^{[10,11]}$ morfologi menggunakan SEM dan TEM, [13,22,23] berat film, $[10,14,16]$ drug permeability, [10] water vapor permeability, $[10,11,16,23]$ sifat mekanik termasuk tensile strength dan elongasi, $[10,11,15,16,18,19,23]$ in vitro drug release $[12,15,16,19,24]$ dan Swab studies. [25]

Banyaknya parameter yang perlu diperhatikan dalam pembentukan sistem film forming, maka dikaji faktor-faktor yang mempengaruhi kualitas FFS. Saat ini, tinjauan publikasi review yang merangkum penelitian-penelitian terkait penggunaan kitosan sebagai basis FFS masih terbatas, oleh sebab itu tinjauan ini dibuat sebagai acuan dalam penyiapan pembentukan FFS yang lebih baik. Sehingga, memiliki kualitas dengan konsistensi yang kuat, penetrasi yang lebih baik saat menggunakan polimer kitosan tunggal maupun kombinasi dengan polimer atau eksipien lainnya. 


\section{Metodologi}

Artikel review ini berdasarkan metode studi pustaka pada beberapa jurnal internasional yang diperoleh dari Scopus, PubMed dan Google Scholar serta situs penyedia jurnal online menggunakan kata kunci "Film Forming System" dan "Chitosan". Pustaka yang diperoleh kemudian diskrining sehingga artikel yang digunakan adalah artikel yang membahas mengenai Film Forming System dan aplikasinya dalam penggunaan medis yang menggunakan kitosan sebagai basis. Artikel yang dipilih merupakan artikel yang diterbitkan 15 tahun terakhir (pada rentang tahun $2005-2020$. Beberapa artikel yang tidak termasuk dalam topik dimasukkan kedalam kategori ekslusi seperti penggunaan kitosan dalam industry teknik, serta tahun penerbitan diluar rentang yang diinginkan, aplikasi kitosan sebagai basis film forming system dalam teknik dan lingkungan.

\section{Hasil dan Pembahasan}

\section{Film Forming System}

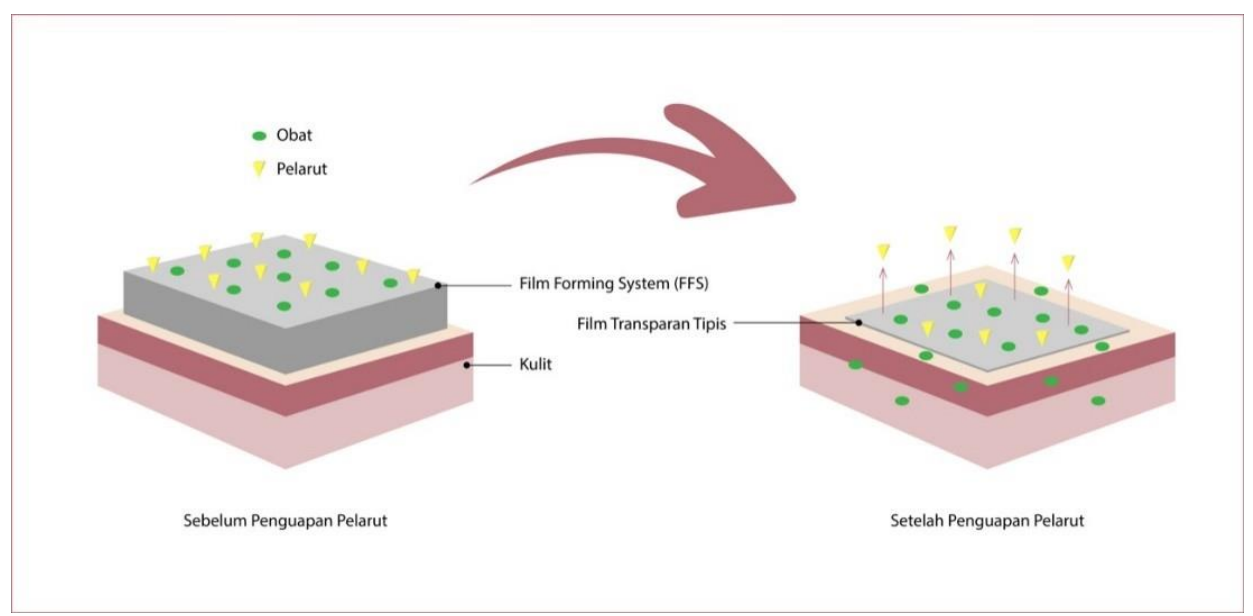

Gambar 2. Mekanisme Film Forming System

Definisi Film Forming System

Topical Film Forming System (TFFS) merupakan salah satu pemberian obat melalui administrasi topikal dengan membentuk film transparan tipis. FFS adalah sediaan non solid yang menghasilkan film in situ saat diaplikasikan pada kulit atau permukaan tubuh lainnya. $[4,26,27]$

\section{Prinsip Film Forming System}

Setelah aplikasi pada kulit, komposisi sistem pembentuk film berubah secara signifikan akibat hilangnya komponen volatile pembawa, sehingga menghasilkan residu film tipis pada permukaan kulit. Pada proses ini berikaitan dengan jenis polimer yang digunakan serta suhu penguapan pelarut. Suhu penguapan pelarut harus lebih tinggi daripada suhu pembentuk film minimum untuk menjamin terjadi koalesensi partikel, sehingga setelah bersentuhan dengan kulit, mampu membentuk film yang sedikit buram dan homogen. [26] 
Film tipis yang terbentuk, memiliki keuntungan yaitu tidak mengganggu aktivitas pasien karena sifatnya yang mengikuti elastisitas kulit. Dibandingkan dengan sediaan konvensional seperti gel, film tipis ini juga memudahkan permease ke kulit dibandingkan dengan patch. Konsentrasi meningkat mencapai kejenuhan bahkan mencapai lewat jenuh, keadaan ini meningkatkan fluks obat melalui kulit karena peningkatan aktivitas termodinamika dari formulasi tanpa mempengaruhi penghalang kulit, sehingga menurunkan efek samping dan iritasi.[4]

\section{Formula Film Forming System Menggunakan Basis Kitosan}

Formula FFS umumnya mengandung campuran obat atau zat aktif, polimer, eksipien berupa plasticizer atau zat tambahan seperti penetration enhancer serta pelarut yang mudah menguap yang dapat mengubah sediaan liquid menjadi film di kulit setelah diaplikasikan. Formula ini biasanya berupa larutan, spray, gel dan emulsi. [26, 27, 28, 20,29,30, 31)

\section{Obat atau Zat Aktif}

Obat atau zat aktif yang ditambahkan harus memiliki kelarutan yang baik pada polimer yang digunakan. Hal ini sangat berpengaruh terhadap kecepatan pelepasan obat. [28] Karena dalam residu film yang terbentuk, konsentrasi obat meningkat cukup besar. ${ }^{[4]}$

\section{Polimer Kitosan}

Polimer merupakan komponen penting dan fungsional dalam FFS. Polimer yang digunakan dalam formulasi dapat digunakan sebagai polimer tunggal maupun dikombinasi dengan polimer lain untuk mendapatkan sifat film yang lebih baik.[32]

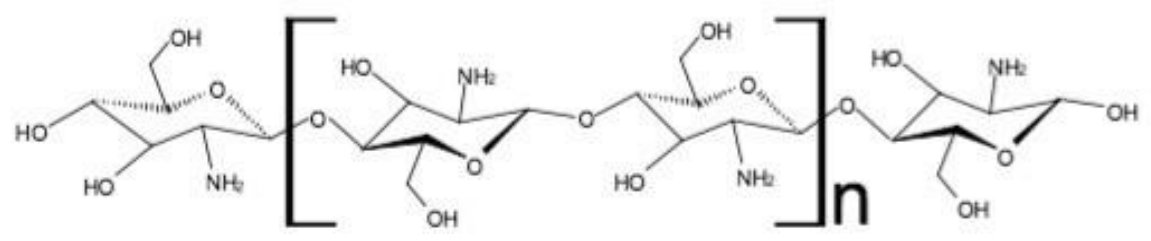

Gambar 2. Struktur Kitosan [33]

Kitosan adalah polimer alami yang terdiri dari glukosamin dan $\mathrm{N}$-asetil glukosamin yang dihubungkan oleh ikatan $\beta$ - $(1,4)$ glikosidik. ${ }^{[34]}$ Kitosan diproduksi dari kitin yang berasal dari hasil pengolahan cangkang crustacea, terutama udang, lobster, kepiting dan cumicumi. Cangkang crustacea mengandung sekitar $15-40 \%$ kitin, serta protein dan kalsium karbonat.[35] Kitin diisolasi dengan cara merendam kulit dari crustaceae dalam larutan $\mathrm{NaOH} 2,5 \mathrm{~N}$ pada suhu $75^{\circ} \mathrm{C}$ dan dengan larutan $\mathrm{HCl}$ pada suhu kamar selama 6 jam. ${ }^{36]}$ Sifat fisika-kimia kitosan dapat dilihat pada Tabel 2. 
Tabel 2. Sifat Fisika-kimia Kitosan [33]

\begin{tabular}{|c|c|}
\hline Karakteristik & Deskripsi \\
\hline Nama Kimia & Kitosan \\
\hline Pemerian & $\begin{array}{l}\text { Kitosan berbentuk serbuk hablur halus, berwarna kuning } \\
\text { muda dan tidak berbau }\end{array}$ \\
\hline Kelarutan & $\begin{array}{l}\text { Kitosan sedikit larut dalam air, praktis tidak larut dalam etanol } \\
(95 \%) \text {, pelarut organic lainnya, dan larutan netral atau alkali } \\
\text { pada } \mathrm{pH} \text { diatas } 6,5 \text {. Kitosan larut dalam asam lemah seperti } \\
\text { larutan asam asetat glacial }\end{array}$ \\
\hline Berat molekul & $10000-1000000$ \\
\hline Titik Leleh & $203^{\circ} \mathrm{C}$ \\
\hline $\mathrm{pH}$ & $4-6$ \\
\hline Stabilitas & $\begin{array}{l}\text { Stabil dalam suhu kamar dan disimpan dalam wadah tertutup } \\
\text { rapat }\end{array}$ \\
\hline Inkompatibilitas & Kitosan tidak kompatibel dengan zat pengoksidasi kuat \\
\hline
\end{tabular}

\section{Plasticizer}

Dalam sediaan FFS, plasticizer berperan dalam menurunkan transition glass temperature $(\mathrm{Tg})$ dari film polimer yang terbentuk serta berperan dalam meningkatkan difusi obat.[20) Selain itu, berperan dalam memberikan fleksibilitas pada film serta meningkatkan tensile strength dari film yang terbentuk. Plasticizer yang digunakan harus sesuai dengan polimer dan memiliki permeabilitas pada kulit yang rendah. Plasticizer yang sering digunakan seperti gliserin, propilenglikol, polyethylene glycol, sorbitol dan lain sebagainya. ${ }^{26]}$

\section{Pelarut}

Penggunaan pelarut pada formulasi FFS membantu dalam melarutkan obat atau zat aktif yang berpengaruh pada permease obat ke kulit. Laju penguapan pelarut berpengaruh dalam pelepasan obat. Penggunaan kombinasi campuran aseton dan isopropyl alkohol dapat mengontrol pelepasan obat jika penguapan pelarut terjadi lambat.[26] Pelarut yang sering digunakan seperti golongan glikol, alkohol, dan pelarut lain seperti asam oleat, etil asetat dan lainnya.

\section{Aplikasi Umum Basis Kitosan dalam Film Forming System}

Kitosan merupakan polimer yang telah banyak digunakan dalam berbagai bidang seperti industri makanan, agricultural, enginereeng maupun obat-obatan. 
Dalam industri makanan, banyak peneliti yang telah melakukan formulasi film forming system menggunakan polimer kitosan tunggal $[37,13,38,39,40]$ maupun yang dikombinasi dengan polimer lain seperti pectin, ${ }^{[41]}$ HPMC, ${ }^{[42]}$ gelatin, $\left.{ }^{[43,44}\right]$ zein, ${ }^{[45]}$ dan alginate. ${ }^{[46)}$ Film yang terbentuk diamati memiliki struktur film yang kompleks, menunjukkan efek lepas lambat yang baik. Memiliki aktivitas antioksidan yang baik untuk menangkal radikal bebas karena kitosan bisa berperan sebagai reduktor yang dimediasi oleh gugus gugus hidroksil dari kitosan, mencegah pembusukan makanan, membentuk film lapis tipis di permukaan makanan dan menghambat kerusakan warna makanan terutama daging. Sehingga, dapat berpotensi digunakan sebagai film kemasan, packaging industry dan bahan lepas lambat yang diterapkan dalam industry makanan maupun farmasi.

Mikroorganisme (termasuk Bacillus cereus, Escherichia coli, Salmonella typhimurium, Staphylococcus aureus, Listeria monocytogenes dan Candida albicans) yang terdapat dalam produk makanan seperti sayur, buah dan daging, dapat menurunkan kualitas, daya tahan, dan nutrisi produk. Kitosan memiliki beberapa mekanisme sebagai antimikroba. Pertama berkaitan dengan interaksi antara muatan positif pada posisi C-2 glukosamin pada kitosan dengan dinding sel mikroorganisme yang bermuatan negatif. Kedua, penggabungan kitosan ke molekul DNA yang menyebabkan penghambatan sintesis mRNA. Interaksi dengan permukaan sel (menghasilkan perubahan permeabilitas sel) atau membentuk lapisan kedap air disekitar sel yang menghalangi pengangkutan zat penting ke dalam sel.[38]

\section{Aplikasi Basis Kitosan dalam Sistem Penghantaran Obat melalui Film Forming System}

Kitosan merupakan polimer yang dapat membentuk matriks dan dapat dimodifikasi dengan polimer lain untuk meningkatkan sifat fisikokimianya. Berikut aplikasi kitosan sebagai penghantaran obat melalui film forming system, dapat dilihat pada Tabel 2.

Pada Tabel 2. terdapat berbagai eksipien maupun kombinasi yang berpengaruh dalam film forming system dan dibahas pada parameter kritis berikut:

\section{Parameter Kritis dalam Formulasi Film Forming System Menggunakan Kitosan}

Pada Tabel 2. Dapat dilihat formulasi sediaan film forming system menggunakan polimer kitosan tunggal $[11,12,14,15,21,47,48]$ ataupun kombinasi menggunakan polimer lain untuk meningkatkan konsistensi kitosan melalui pembentukan ikatan silang, seperti polyvinyl alcohol [10, 17] dan poloxamer.[24] 
Tabel 2. Basis biopolimer kitosan dalam sistem penghantaran obat melalui film forming

\begin{tabular}{|c|c|c|c|c|}
\hline Polimer & Eksipien & Tipe FFS & Aktivitas & Ref \\
\hline $\begin{array}{l}\text { Kitosan-polyvinyl } \\
\text { alcohol }\end{array}$ & & solution & $\begin{array}{l}\text { developed new chitosan } \\
\text { aquaeous dipersion as ffs }\end{array}$ & [10] \\
\hline Kitosan & Asam oleat & emulsion & Evaluasi efek antifungal & [11] \\
\hline Kitosan & & hydrogel & $\begin{array}{l}\text { Inovasi formulasi hidrogel } \\
\text { mengandung capsaicinoids } \\
\text { dalam nanokapsulpolimer }\end{array}$ & [12] \\
\hline
\end{tabular}

Kitosan Propilenglikol solution Delivery of imiquimod for basal cell carcinoma

\begin{tabular}{|c|c|c|c|c|}
\hline Kitosan & $\begin{array}{c}\text { Lactic acid } \\
\text { Propilenglikol }\end{array}$ & gel & $\begin{array}{l}\text { Prepare chitosan based film } \\
\text { forming gel containing ketoprofen }\end{array}$ & [21] \\
\hline Kitosan-poloxamer & & solution & $\begin{array}{l}\text { Topical ocular delivery of } \\
\text { fluconazole for antifungalagent }\end{array}$ & [24] \\
\hline Kitosan & Plasticizer & solution & $\begin{array}{l}\text { Development and } \\
\text { characterization of FFS polymeric }\end{array}$ & [30] \\
\hline Kitosan & & gel & Wound healing & [47] \\
\hline Kitosan & & gel & Burn wounds & [48] \\
\hline Kitosan & & solution & $\begin{array}{l}\text { Mengamati pengaruh derajat } \\
\text { deasetilasi terhadap film forming } \\
\text { dalam penyembuhan luka }\end{array}$ & [49] \\
\hline
\end{tabular}

Kitosan

Gliserol

solution Produksi film forming solution 
Banyak faktor yang dapat mempengaruhi pembentukan film dari kitosan diantaranya pengaruh penambahan eksipien. Pada formulasi film forming system dengan polimer kitosan, diamati bahwa sifat reologi dari FFS bergantung pada konsentrasi kitosan, sedangkan kitosan yang diformulasikan dengan gliserol menyebabkan perubahan dari struktur film yang dapat diamati dari sifat mekanik ${ }^{[10,50,51]}$ dan perubahan kisi kristal film kitosan. Mekanisme ini diperantai oleh adanya perubahan ikatan $\mathrm{H}$ dalam kisi kristal kitosan, yang ditunjukkan dari hasil analisis FTIR, dimana kelompok interaksi yang berbeda teramati sesuai dengan rasio kitosan dengan gliserol.[50] Interaksi antara plasticizer, molekul air dan rantai polimer kitosan memiliki peranan penting dalam meningkatkan konsistensi film, berperan pada FFS dan dapat mempengaruhi penguapan air selama pengeringan film. ${ }^{[50]}$

Konsentrasi kitosan berpengaruh pada perilaku reologis FFS, mulai dari mendekati Newtonian pada konsentrasi kitosan yang rendah, hingga perilaku pseudoplastik ketika konsentrasi kitosan meningkat.[50] Ketebalan film dipengaruhi secara signifikan oleh konsentrasi kitosan. Pada kitosan dengan konsentrasi rendah, penambahan plasticizer meningkatkan elongation break, dan menurunkan tensile strength. Efek ini disebabkan oleh interaksi rantai kitosan, penurunan tarikan antar molekul dan peningkatan mobilitas polimer, yang memfasilitasi perpanjangan film. ${ }^{[51]}$

Pengembangan kitosan yang didispersikan dalam air (non asam) dapat mengatasi keterbatasan kitosan yang memiliki residu asam dan sifat mekanik yang buruk jika didespersikan dalam asam asetat. Dibandingkan dengan film dari larutan kitosan yang didispersikan dalam asam asetat, film dari dispersi cair kitosan memiliki kadar asam 4,9 kali lebih rendah. ${ }^{10]}$

Selain itu, pengaruh derajat deasetilasi dari kitosan memiliki dampak terhadap sifat reologi, termal, pembentukan filmn ${ }^{[49]}$ dan pada aktivitas penyembuhan luka. ${ }^{[48]}$ Penentuan sifat viskoelastik dinamis dari larutan kitosan menunjukkan perilaku khas non Newtonian seperti kental, dengan nilai viskositas yang lebih tinggi pada tingkat asetilasi yang lebih rendah. Selain itu, suhu gelasi kitosan kepiting biru memiliki nilai yang lebih rendah pada tingkat asetilasi yang lebih rendah. Stabilitas termal kitosan, profil termogravimetri mengungkapkan resistensi termal yang lebih besar untuk kitosan dengan derajat asetilasi yang lebih rendah, menunjukkan suhu degradasi yang jauh lebih tinggi. Demikian juga, nilai-nilai suhu transisi gelas menurun dengan meningkatnya derajat asetilasi. Di sisi lain, film berbasis kitosan, dengan derajat asetilasi lebih rendah, akan menghasilkan film yang lebih fleksibel, tahan, dan transparan. [51] 
Penambahan asam oleat dalam formula gel film forming system yang mengandung ketoprofen berpengaruh terhadap morfologi film yang terbentuk. Penambahan asam oleat menyebabkan ketidakteraturan bentuk permukaan, terjadi peningkatan jumlah dan ukuran globul ketika konsentrasi asam oleat dalam formula meningkat yang diamati pada morfologi film. Pembentukan globul ini berkaitan dengan okulasi kitosan dan asam oleat. ${ }^{[11]}$ Reaksi kitosan dengan asam oleat adalah katalisis yang beraksi dengan gugus karboksil asam oleat untuk menghasilkan bahan aktif ester, bahan aktif ester ini kemudian bereaksi dengan gugus amino primer dari kitosan untuk membentuk ikatan amida.[52] Komposisi asam oleat juga mempengaruhi aktivitas permease kulit film.

Penambahan asam oleat ke formulasi minyak esensial kitosan meningkatkan stabilitas emulsi dan retensi minyak dalam film, pada saat yang sama meningkatkan sifat penghalang uap air film. Ketika asam oleat OA ditambahkan dalam formula, perubahan warna dipicu oleh minyak esensial, OA mengurangi transparansi film. Film-film kitosan dengan minyak esensial thyme atau basil tidak menghambat pertumbuhan jamur yang diuji. [11]

Penggunaan kitosan yang dikombinasi dengan polimer lain seperti polyvinyl alkohol [10] ditemukan memiliki kekuatan tarik yang lebih tinggi, elongasi yang lebih tinggi, penyerapan air yang lebih rendah dan penurunan berat film, serta permeabilitas obat .yang lebih rendah. Hasil ini menunjukkan bahwa kombinasi kitosan dengan PVA dapat memberikan sifat mekanik yang lebih baik dan penurunan laju difusi obat dari matriks kitosan sehingga mampu memberikan durasi kerja yang lebih lama. Penelitian lain yang telah dilakukan, menunjukkan bahwa konsentrasi yang digunakan merupakan salah satu kunci keberhasilan LFFS, kombinasi kitosan dengan 5\% PVA menghasilkan incompact dan asymmetric morfologi, memiliki stabilitas yang baik dan pelepasan yang lambat atau terkontrol pada $\mathrm{pH} 4,6$, dan 8.[17]

Penelitian lain pada sediaan dengan fluconazole yang ditujukan untuk fungal keratitis menggunakan polimer kitosan yang dikombinasikan dengan poloxamer dilakukan secara in vivo. Dari hasil penelitian diperoleh peningkatan kekuatan tarik yang berpengaruh pada difusi obat sehingga mampu meningkatkan permease obat ke target. Selain itu, kombinasi ini berpengaruh pada laju pelepasan FLU lebih tinggi daripada larutan encer.[24]

Formulasi krim topikal Aldara ${ }^{\mathrm{TM}}$ ( $5 \% \mathrm{w} / \mathrm{w}$ imiquimod) yang telah disetujui oleh FDA AS untuk pengobatan karsinoma sel basal superfisial. Namun, formulasi krim memiliki variabilitas dosis yang buruk, ketersediaan obat yang rendah karena pelepasan yang tidak sempurna, dan kepatuhan pasien yang buruk. Untuk mencapai pelepasan imiquimod yang berkelanjutan dan lengkap, formulasi film kitosan dikombinasikan dengan propilenglikol sebagai humektan. Dari hasil penelitian ini diperoleh film kitosan yang memiliki karakteristik fisikokimia yang tepat untuk pembalut luka dan keseragaman konten yang sangat baik dan mempertahankan bentuk fisik asli imiquimod. 
Bioaktivitas imiquimod tidak dipengaruhi oleh jumlah obat yang terjerap dalam matriks kitosan seperti yang ditunjukkan oleh hasil uji penghambatan pertumbuhan in vitro. Selain itu, formulasi film menunjukkan secara signifikan $(p 0,05)$ akumulasi obat yang lebih tinggi di kulit jika dibandingkan dengan formulasi krim komersial. [15]

Studi yang dilakukan dalam formulasi film menggunakan kitosan yang ditujukan untuk meningkatkan sifat fisikokimianya menggunakan kalium pirofosfat dan natrium tripolifosfat sebagai crosslinker. Dari penelitian ini diperoleh bahwa film yang diformulasikan dengan penambahan crosslinker menunjukkan perubahan dalam durasi perawatan yang memungkinkan tingkat pembengkakan bervariasi pada kisaran $165 \%$ hingga $148 \%$ untuk kalium pirofosfat dan dari 196\% menjadi $80 \%$ untuk natrium tripolifosfat. Studi kinetika pelepasan obat menunjukkan bahwa perubahan dalam kondisi yang digunakan untuk modifikasi dengan polifosfat dapat meningkatkan durasi pelepasan komponen aktif biologis hingga 8 jam.[14]

Preparasi gel film forming system dilakukan dengan basis kitosan dengan konsentrasi $3 \%$ dan $2 \%$ propilenglikol untuk pembentukan viskositas yang tepat, yang mengandung ketoprofen (CbFG) sebagai agen anti inflamasi dan analgesik. Hasil dari penelitian ini menunjukkan bahwa CbFG yang mengandung asam oleat diperoleh disperse kitosan kental dan transparan. Perubahan transparansi dari sediaan gel menjadi film setelah diaplikasikan berubah menjadi buram dengan cepat, ketika gel benar-benar sudah kering setelah 10 menit, film CbFG berubah transparan. Gel yang mengandung asam oleat menyebabkan peningkatan modulus elastisitas dan kekuatan tarik serta perpanjangan maksimum saat putus. Gel memiliki tingkat permease kulit yang lebih tinggi dibandingkan dengan kandidat peningkat lainnya. ${ }^{[21]}$

\section{Parameter Fisikokimia Film Forming System}

Parameter fisikokimia dalam film forming system dievaluasi menggunakan beberapa pendekatan seperti viskositas, ${ }^{[10,11,12]} \mathrm{pH}$ solution, $[12,13,14,15,16]$ drying time, ${ }^{[17,18]}$ hardness, adhesiveness, sticknessl, $[19,20]$ cosmetic appearance, ${ }^{[21]}$ particle size analysis, ${ }^{[10,11]}$ morfologi menggunakan SEM dan TEM, [13, 22, 23] berat film, [10, 14, 16] drug permeability, ${ }^{[10]}$ water vapor permeability, ${ }^{[10,14,16,23]}$ sifat mekanik termasuk tensile strength dan elongasi, [10, 11, 15, 16, 18, 19, 23] in vitro drug release [12, 15, 16, 19, 24] dan Swab studies, [25] Spektrofotometer UV, ${ }^{[14]}$ FTIR, $\left.{ }^{21,} 10,15,\right]$ XRD, ${ }^{21,}$ 15] DSC, ${ }^{[21]}$ glass transition temperature, ${ }^{[10]}$ minimum film formation temperature, ${ }^{[10]}$ extendsibility. ${ }^{[16]}$

\section{Mechanical properties}

Mechanical properties adalah salah satu parameter lain yang digunakan untuk memastikan modulus elastisitas film tidak melebihi elastisitas stratum coreneum dan untuk memastikan kontak yang berkepanjangan dengan kulit.[26] Selain itu, untuk mengkarakterisasi film polimer untuk ketahanan abrasi dan fleksibilitasnya. [30] 
Tabel 2. Karakterisasi Film Forming System

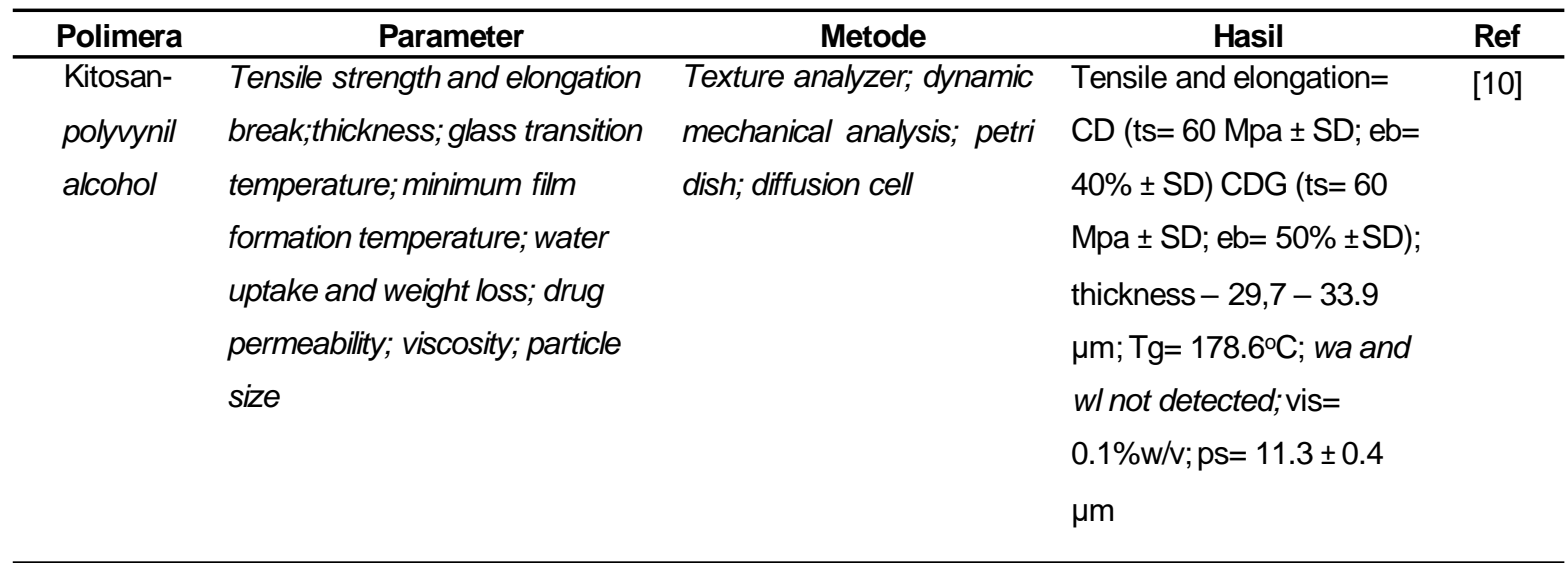

\begin{tabular}{|c|c|c|c|c|}
\hline Kitosan & $\begin{array}{l}\text { Particle size; zeta potential; } \\
\text { rheological;thickness; water } \\
\text { vapour permeability; mechanical } \\
\text { properties; }\end{array}$ & $\begin{array}{l}\text { Laser diffractometer; laser } \\
\text { Doppler electrophoresis; } \\
\text { rotational rheometer; palmer } \\
\text { digital micrometer; texture } \\
\text { analyszer; }\end{array}$ & $\begin{array}{l}\text { Berukuran } 0.07 \text { dan } 1.3 \\
\mu \mathrm{m} \text {; potensial zeta }= \\
1.3 \mathrm{mV} \text {; thickness }=50 \mu \mathrm{m}\end{array}$ & [11] \\
\hline Kitosan & $\begin{array}{l}\mathrm{pH} \text {; rheological; invitro release } \\
\text { study }\end{array}$ & $\begin{array}{l}\text { Potentiometer; brookfiled } \\
\text { viscometer; dialysis bag }\end{array}$ & $\begin{array}{l}\mathrm{pH}=4.2 \text { dan } 4.4 ; \\
\text { rheological= } \\
\text { pseudoplastik; setelah } 96 \\
\text { jam }=81 \pm 1 \%\end{array}$ & [12] \\
\hline $\begin{array}{l}\text { Kitosan- } \\
\text { polyvinyl } \\
\text { alcohol }\end{array}$ & $\begin{array}{l}\text { Morfologi film; invitro drug } \\
\text { release; thickness; stabilitas; FFS } \\
\text { ability; pH }\end{array}$ & $\begin{array}{l}\text { Scanning electron } \\
\text { microscope (SEM); dialysis } \\
\text { bag; sentrifugasi; } \\
\text { organoleptis;pH meter }\end{array}$ & $\begin{array}{l}\text { Incompact and asymmetric } \\
\text { morphology with Irregular } \\
\text { shape; sustained release } \\
90 \% \text { dalam waktu } 96 \text { jam; } \\
\text { stabil; transparan dan } \\
\text { bening; } \mathrm{pH}=6,8\end{array}$ & [17] \\
\hline Kitosan & $\begin{array}{l}\text { Viskositas; morfologi film; tensile } \\
\text { strength and elongation break; } \\
\text { invitro study; drying time }\end{array}$ & $\begin{array}{l}\text { Viskometer; Scanning } \\
\text { electron microscope (SEM); } \\
\text { texture analyzer; Franz } \\
\text { diffusion cell; timer }\end{array}$ & $\begin{array}{l}5000 \mathrm{cP} ; \text { globul shape; } \\
\text { tensile }=1,6 \mathrm{~N} \text { and } \\
\text { elongation }=98 \mathrm{~mm} ; \text { drug } \\
\text { release }=75.4 \pm 5.0\end{array}$ & [21] \\
\hline Kitosan & $\begin{array}{l}\text { Tensile strength and elongation } \\
\text { break; water vapour permeability; } \\
\text { viscosity; stickness;drying time }\end{array}$ & $\begin{array}{l}\text { Tensile tester; hygrometer; } \\
\text { viscometer;cotton wool; } \\
\text { timer }\end{array}$ & $\begin{array}{l}\text { Viskositas= high; } \\
\text { stickness=rendah (tidak } \\
\text { ada wool yang tertinggal; } \\
\text { drying time=>7menit }\end{array}$ & [31] \\
\hline Kitosan & $\begin{array}{l}\text { Rheological; film water activity } \\
\text { and moisture content; thickness; } \\
\text { mechanical properties; film } \\
\text { thermal properties }\end{array}$ & $\begin{array}{l}\text { Viscometer; } \\
\text { hygrometer;digital } \\
\text { micrometer; Instron } \\
\text { Universal testing machine; } \\
\text { differential scanning } \\
\text { calorimetry (DSC) }\end{array}$ & $\begin{array}{l}\text { Rheology dari konsentrasi } \\
\text { rendah= Newtonian, } \\
\text { konsentrasi tinggi }\end{array}$ & [50] \\
\hline
\end{tabular}


Sifat mekanik dari film yang terbentuk harus dapat mengatasi tekanan tangensial karena gerakan tubuh.[26] Sifat mekanik dipengaruhi oleh jenis dan jumlah polimer. Konsentrasi yang terlalu rendah dapat menyebabkan pembentukan film yang terputusputus atau dengan resistensi mekanik yang buruk, sementara konsentrasi tinggi menghasilkan film yang tebal dan kaku pada kulit, tidak nyaman digunakan dan dapat menunda pelepasan obat.[52] Peningkatan sifat mekanik juga merupakan pengaruh dari penambahan plasticizer yang dapat meningkatkan rongga diantara rantai polimer sehingga dapat meningkatkan mobilitasnya.[26]

Kekuatan tarik dapat ditentukan dengan tensile strength tester. Kemudian dihitung :

$$
\text { Tensile tester }(\sigma)=\mathrm{Fmax} / \mathrm{A}\left(\mathrm{Nm}^{2}\right)
$$

Dimana, Fmax $(\mathrm{N})$ adalah kekuatan maksimum dan $\mathrm{A}\left(\mathrm{m}^{2}\right)$ adalah luas penampang film. ${ }^{[30]}$ Sedangkan elongation at break dihitung dengan:

$$
\varepsilon=\frac{L R}{L 0} \times 100(\%)
$$

Dimana, LR $(\mathrm{m})$ adalah ekstensi sampel pada saat pecah dan L0 (m) adalah panjang sampel awal.[30]

\section{$\mathrm{pH}$}

$\mathrm{pH}$ formulasi idealnya berkisar pada $4-6$, sehingga dapat meminimalkan ketidaknyamanan atau iritasi karena $\mathrm{pH}$ asam dan pertumbuhan mikroba.[27] Sedangkan $\mathrm{pH}$ di daerah luka berkisar pada rentang $7-8 .{ }^{[17]}$

\section{Drying Time}

Untuk melakukan pengujian waktu pengeringan film, maka sampel diaplikasikan pada sisi bgian dalam lengan sukarelawan. Setelah 2 menit, slide kaca ditempatkan pada film tanpa tekanan. Jika tidak ada sisa-sisa cairan yang terlihat pada kaca setelah dikeluarkan maka film telah dianggap kering. Idealnya, sediaan topikal harus mongering untuk membentuk film tipis yang tidak terlihat pada permukaan lokasi aplikasi dalam 5 menit, sehingga meminimalkan ketidaknyamanan bagi pasien.[30]

\section{Stickness}

Film yang terbentuk harus kering dan tidak mengganggu aktivitas pasien, tidak lengket pada pakaian, dan dapat tinggal lebih lama di kulit. Untuk menghindari lengketnya film pada pakaikan, kelekatan film dapat diuji secara kualitatif dengan menekan kapas pada film kering dibawah tekanan rendah. Kemudian dilakukan penilaian tergantung pada jumlah kapas yang tertinggal pada film. ${ }^{[26]}$ 
Selain itu, untuk melihat lamanya film dapat tertinggal dikulit, dilakukan pengujian swab study menggunakan kapas kering dan basah. Dry swab test menggunakan kapas kering dilakukan untuk melihat film pada kulit dalam kondisi kering. Sedangkan Wet swab test dilakukan untuk melihat sifat film dan waktu tinggal film ketika bersentuhan dengan air atau keringat. Pengujian swab study dilakukan dengan prosedur yang sama, pada pelat kaca. Pelat dibagi menjadi 6 kotak sama besar, dan dilakukan pengujian swab pada 30 menit, 2 jam, 4 jam, 6 jam dan 8 jam. Kandungan obat dapat diperiksa pada waktu tersebut dengan cara ekstraksi obat dari kapas swab.[30]

\section{Water Vapour Permeability}

Water vapour permability adalah jumlah air yang ditransmisikan melalui film per satuan waktu. Hal ini penting dalam menentukan karakteristik perforasi film kareka memiliki pengaruh terhadap sifat kulit seperti hidrasi stratum korneum, aliran darah dan suhu kulit.[26]

Water vapour permeability dilakukan menggunakan sel permease menggunakan ampel dengan diameter $2,0 \mathrm{~cm}$ yang dipotong. $10 \mathrm{ml}$ botol kaca dengan diameter mulut botol $1,2 \mathrm{~cm}\left(A=1,13 \mathrm{~cm}^{2}\right)$ diisi dengan $8 \mathrm{~g}$ air suling, sampel diletakkan pada mulut botol dan dijepit menggunakan penjepit supaya lebih rapat dan tidak terdapat rongga. Botol ditempatkan dalam exsiccator untuk menciptakan iklim dengan kelembaban relative rendah (sekitar 0\%). Kemudian, disimpan pada suhu yang ditetapkan yaitu 25, 32 dan $37^{\circ} \mathrm{C}$ dan disesuaikan dengan suhu kamar selama 1 jam. Dari penurunan berat botol W (g), WVP dihitung sebagai jumlah air yang telah menembus film yang berkaitan dengan luas permukaan $\mathrm{A}\left(\mathrm{cm}^{2}\right)$ dan waktu per jam.

$$
\mathrm{WVP}=\frac{W}{A \times T}\left(\mathrm{gr} / \mathrm{cm}^{2} \times 24 \mathrm{jam}\right)
$$

Bahan dapat dianggap permeable terhadap uap air jika nilai WVP melebihi 0,05 $\mathrm{g} / \mathrm{cm}^{2} .24$ jam.[30]

\section{Morfologi Film}

Morfologi film diamati untuk memvisualisasikan permukaan film dan ukuran partikel film kitosan. Morfologi film dapat dilakukan menggunakan scanning electron microscopy (SEM) $[12,17,21,37,47)$ yang memberikan informasi detail umum tentang ukuran dan bola morfologi. Film dikeringkan terlebih dahulu menggunakan oven dengan suhu $40^{\circ} \mathrm{C}$ selama 30 menit hingga film terbentuk. Film kemudian dilapisi dengan gold film dan diamati dalam SEM. Struktur permukaan kitosan diamati halus dan tidak rata. Karakteristik permukaan film memiliki peranan penting terhadap penyerapan air. ${ }^{[12]}$ 


\section{In Vitro Drug Release}

Pengujian pelepasan obat untuk film forming system banyak dilakukan menggunakan metode diffusion franz. Profil pelepasan obat dengan metode diffusion franz sering dievaluasi menggunakan kulit punggung tikus sebagai membrane. Kulit dipasang langsung pada alat dan sampel diaplikasikan pada kulit yang kemudian dihubungkan dengan fase reseptor menggunakan larutan buffer. Buffer digunakan untuk menyesuaikan kondisi dalam tubuh manusia. Hasil pengujian dianalisis menggunakan spektrofotometer UV ataupun HPLC untuk menghitung kadar obat yang telah dilepaskan dalam satuan waktu tertentu. ${ }^{[12]}$

\section{Kesimpulan}

Film forming system yang diformulasikan menggunakan polimer kitosan telah banyak diaplikasikan dalam sistem penghantaran obat dengan berbagai aktivitas biologi seperti antifungal, antibakteri dan antimikroba, serta dalam terapi penyembuhan luka. Pemilihan konsentrasi polimer, kombinasi dengan polimer lain, derajat deasetilasi, penambahan eksipen seperti humectan, plasticizer dan crosslinker berpengaruh pada parameter fisikokimia dalam meningkatkan sifat mekanik dan pelepasan obat. Parameter fisikokimia dilihat melalui beberapa karakterisasi seperti mechanical properties, drying time, $\mathrm{pH}$, stickness, water vapour permeability, morfologi film dan studi in vitro drug release.

\section{Ucapan Terimakasih}

Terima kasih kepada Bapak Dr. apt. Sriwidodo, M.Si. dan Bapak Dr. apt. Yoga Windhu Wardhana, M. Si. sebagai pembimbing yang telah memberikan saran dalam pembuatan review artikel ini.

\section{Referensi}

1. Rastogi V, Yadav P. Transdermal drug delivery system: An overview. Asian J Pharm. 2012;6(3):161-70.

2. Jain KK. An Overview of Drug Delivery Systems. Vol. 2059, Methods in Molecular Biology. 2020. 1-54 p.

3. Weiss SC. Conventional topical delivery systems. Dermatol Ther. 2011;24(5):471-6.

4. Frederiksen K, Guy RH, Petersson K. The potential of polymeric film-forming systems as sustained delivery platforms for topical drugs. Expert Opin Drug Deliv. 2016;13(3):349-60.

5. Tran TTD, Tran PHL. Controlled release film forming systems in drug delivery: The potential for efficient drug delivery. Pharmaceutics. 2019;11(6):1-16.

6. Ahsan SM, Thomas M, Reddy KK, Sooraparaju SG, Asthana A, Bhatnagar I. Chitosan as biomaterial in drug delivery and tissue engineering. Int $\mathrm{J}$ Biol Macromol [Internet]. 2018;110:97-109. Available from: http://dx.doi.org/10.1016/j.ijbiomac.2017.08.140. 
7. Nagarajan E, Shanmugasundaram P, Ravichandiran V, Vijayalakshmi A, Senthilnathan B, Masilamani K. Development and evaluation of chitosan based polymeric nanoparticles of an antiulcer drug Lansoprazole. J Appl Pharm Sci. 2015;5(4):20-5.

8. Gierszewska M, Ostrowska-Czubenko J. Chitosan-based membranes with different ionic crosslinking density for pharmaceutical and industrial applications. Carbohydr Polym [Internet]. 2016;153:501-11. Available from: http://dx.doi.org/10.1016/i.carbpol.2016.07.126.

9. Monti D, Tampucci S, Chetoni P, Burgalassi S, Mailland F. Ciclopirox vs amorolfine: In vitro penetration into and permeation through human healthy nails of commercial nail lacquers. J Drugs Dermatology. 2014;13(2):143-7.

10. Sakwanichol J, Sungthongjeen S, Puttipipatkhachorn S. Preparation and characterization of chitosan aqueous dispersion as a pharmaceutical film forming material. J Drug Deliv Sci Technol [Internet]. 2019;54(August):101230. Available from: https://doi.org/10.1016/i.jddst.2019.101230.

11. Perdones Á, Chiralt A, Vargas M. Properties of film-forming dispersions and films based on chitosan containing basil or thyme essential oil. Food Hydrocoll. 2016;57:271-9.

12. Contri R V., Katzer T, Pohlmann AR, Guterres SS. Chitosan hydrogel containing capsaicinoids-loaded nanocapsules: An innovative formulation for topical delivery. Soft Mater. 2010;8(4):370-85.

13. M Loai NA, Mohamed Som HZ, Abdul Haiyee Z. Effect of Edible Lipid-Chitosan Film Forming Dispersion on Postharvest Life of Guava Stored At Chilled Temperature. Malaysian J Anal Sci. 2016;20(3):618-25.

14. Kasatkina MA, Budantseva NA, Kil'deeva NR. Preparation of Biologically Active Film-Forming Materials Based on Polyphosphate-Modified Chitosan. Pharm Chem J. 2016;50(4):250-7.

15. Layek B, Rahman Nirzhor SS, Rathi S, Kandimalla KK, Wiedmann TS, Prabha S. Design, Development, and Characterization of Imiquimod-Loaded Chitosan Films for Topical Delivery. AAPS PharmSciTech. 2019;20(2):1-12.

16. Thakur G, Singh A, Singh I. Formulation and evaluation of transdermal composite films of chitosan-montmorillonite for the delivery of curcumin. Int $\mathrm{J}$ Pharm Investig. 2016;6(1):23.

17. Yang S, Yang Y, Cui S, Feng Z, Du Y, Song Z, et al. Chitosan-polyvinyl alcohol nanoscale liquid film-forming system facilitates MRSA-infected wound healing by enhancing antibacterial and antibiofilm properties. Int $\mathrm{J}$ Nanomedicine. 2018;13:4987-5002.

18. Kim DW, Kim KS, Seo YG, Lee BJ, Park YJ, Youn YS, et al. Novel sodium fusidateloaded film-forming hydrogel with easy application and excellent wound healing. Int $\mathrm{J}$ Pharm [Internet]. 2015;495(1):67-74. Available from: http://dx.doi.org/10.1016/j.ijpharm.2015.08.082.

19. Hurler J, Škalko-Basnet N. Potentials of Chitosan-Based Delivery Systems in Wound Therapy: Bioadhesion Study. J Funct Biomater. 2012;3(1):37-48.

20. Frederiksen K, Guy RH, Petersson K. Formulation considerations in the design of topical, polymeric film-forming systems for sustained drug delivery to the skin. Eur $\mathrm{J}$ Pharm Biopharm [Internet]. 2015;91:9-15. Available from: http://dx.doi.org/10.1016/j.ejpb.2015.01.002. 
21. Oh DW, Kang JH, Lee HJ, Han SD, Kang MH, Kwon YH, et al. Formulation and in vitro/in vivo evaluation of chitosan-based film forming gel containing ketoprofen. Drug Deliv [Internet]. 2017;24(1):1056-66. Available from: https://doi.org/10.1080/10717544.2017.1346001.

22. Garvie-Cook H, Frederiksen K, Petersson K, Guy RH, Gordeev S. Characterization of topical film-forming systems using atomic force microscopy and Raman microspectroscopy. Mol Pharm. 2015;12(3):751-7.

23. Liu J, Pu H, Zhang X, Xiao L, Kan J, Jin C. Effects of ascorbate and hydroxyl radical degradations on the structural, physicochemical, antioxidant and film forming properties of chitosan. Int J Biol Macromol [Internet]. 2018;114:1086-93. Available from: https://doi.org/10.1016/j.ijbiomac.2018.04.021.

24. Gratieri T, Gelfuso GM, De Freitas O, Rocha EM, Lopez RFV. Enhancing and sustaining the topical ocular delivery of fluconazole using chitosan solution and poloxamer/chitosan in situ forming gel. Eur J Pharm Biopharm. 2011;79(2):320-7.

25. Lunter DJ, Daniels R. New film forming emulsions containing Eudragit $\AA$ NE and/or RS 30D for sustained dermal delivery of nonivamide. Eur $\mathrm{J}$ Pharm Biopharm [Internet]. 2012;82(2):291-8. Available from: http://dx.doi.org/10.1016/j.ejpb.2012.06.010.

26. Gennari CGM, Selmin F, Franzè S, Musazzi UM, Quaroni GMG, Casiraghi A, et al. A glimpse in critical attributes to design cutaneous film forming systems based on ammonium methacrylate. J Drug Deliv Sci Technol. 2017;41:157-63.

27. Vij NN, Saudagar RB. Formulation, development and evaluation of film-forming gel for prolonged dermal delivery of terbinafine hydrochloride. Int J Pharma Sci Res [Internet]. 2014;5(9):537. Available from: http://ezproxy.si.unav.es:2048/login?url=http://search.ebscohost.com/login.aspx?dire ct=true\&AuthType $=i p, u r l \& d b=e d s d o j \& A N=e d s d o j . b d c 82 a 84474 c 4 e b 1 b 31 a 2 f 1 d 0 d 9 d$ 2cbc\&lang=es\&site $=$ eds-live\&scope $=$ site.

28. Edwards A, Qi S, Liu F, Brown MB, McAuley WJ. Rationalising polymer selection for supersaturated film forming systems produced by an aerosol spray for the transdermal delivery of methylphenidate. Eur J Pharm Biopharm. 2017;114:164-74.

29. T. R, Chiam-Wen L, Pui L, Morris E. Characterization of High Molecular Weight Poly(vinyl chloride) - Lithium Tetraborate Electrolyte Plasticized by Propylene Carbonate. Recent Advances in Plasticizers. 2012.

30.Zurdo Schroeder I, Franke P, Schaefer UF, Lehr CM. Development and characterization of film forming polymeric solutions for skin drug delivery. Eur $\mathrm{J}$ Pharm Biopharm. 2007;65(1):111-21.

31. Kathe K, Kathpalia H. Film forming systems for topical and transdermal drug delivery. Asian J Pharm Sci [Internet]. 2017;12(6):487-97. Available from:

http://dx.doi.org/10.1016/i.ajps.2017.07.004.

32. Karki S, Kim H, Na SJ, Shin D, Jo K, Lee J. Thin films as an emerging platform for drug delivery. Asian J Pharm Sci [Internet]. 2016;11(5):559-74. Available from: http://dx.doi.org/10.1016/j.ajps.2016.05.004.

33. Rowe, C. R; Sheskey, J. P; Quinn M. Handbook of Pharmaceutical Exipient. 6th ed. Pharmaceutical Press; 2009. $159 \mathrm{p}$.

34. Butko A, Bonat Celli G, Paulson A, Ghanem A. Entrapment of basic fibroblast growth factor (bFGF) in a succinylated chitosan nanoparticle delivery system and release profile. J Biomater Sci Polym Ed. 2016;27(10):1045-57. 
35. Gratieri T, Gelfuso GM, De Freitas O, Rocha EM, Lopez RFV. Enhancing and sustaining the topical ocular delivery of fluconazole using chitosan solution and poloxamer/chitosan in situ forming gel. Eur J Pharm Biopharm. 2011;79(2):320-7.

36. Lunter DJ, Daniels R. New film forming emulsions containing Eudragit@ NE and/or RS 30D for sustained dermal delivery of nonivamide. Eur $\mathrm{J}$ Pharm Biopharm [Internet]. 2012;82(2):291-8.

http://dx.doi.org/10.1016/i.ejpb.2012.06.010.

37. Gennari CGM, Selmin F, Franzè S, Musazzi UM, Quaroni GMG, Casiraghi A, et al. A glimpse in critical attributes to design cutaneous film forming systems based on ammonium methacrylate. J Drug Deliv Sci Technol. 2017;41:157-63.

38. Vij NN, Saudagar RB. Formulation, development and evaluation of film-forming gel for prolonged dermal delivery of terbinafine hydrochloride. Int J Pharma Sci Res [Internet]. 2014;5(9):537.

Available from: http://ezproxy.si.unav.es:2048/login?url=http://search.ebscohost.com/login.aspx?dire ct=true\&AuthType=ip,url\&db=edsdoj\&AN=edsdoj.bdc82a84474c4eb1b31a2f1d0d9d 2cbc\&lang=es\&site=eds-live\&scope=site.

39. Edwards A, Qi S, Liu F, Brown MB, McAuley WJ. Rationalising polymer selection for supersaturated film forming systems produced by an aerosol spray for the transdermal delivery of methylphenidate. Eur J Pharm Biopharm. 2017;114:164-74.

40. T. R, Chiam-Wen L, Pui L, Morris E. Characterization of High Molecular Weight Poly(vinyl chloride) - Lithium Tetraborate Electrolyte Plasticized by Propylene Carbonate. Recent Advances in Plasticizers. 2012.

41.Zurdo Schroeder I, Franke P, Schaefer UF, Lehr CM. Development and characterization of film forming polymeric solutions for skin drug delivery. Eur $\mathrm{J}$ Pharm Biopharm. 2007;65(1):111-21.

42. Kathe K, Kathpalia $\mathrm{H}$. Film forming systems for topical and transdermal drug delivery. Asian J Pharm Sci [Internet]. 2017;12(6):487-97. Available from: http://dx.doi.org/10.1016/i.ajps.2017.07.004.

43. Karki S, Kim H, Na SJ, Shin D, Jo K, Lee J. Thin films as an emerging platform for drug delivery. Asian J Pharm Sci [Internet]. 2016;11(5):559-74. Available from: http://dx.doi.org/10.1016/j.ajps.2016.05.004.

44. Rowe, C. R; Sheskey, J. P; Quinn M. Handbook of Pharmaceutical Exipient. 6th ed. Pharmaceutical Press; 2009. 159 p.

45. Butko A, Bonat Celli G, Paulson A, Ghanem A. Entrapment of basic fibroblast growth factor (bFGF) in a succinylated chitosan nanoparticle delivery system and release profile. J Biomater Sci Polym Ed. 2016;27(10):1045-57.

46. Kulig D, Zimoch-Korzycka A, Kró Z, Oziembłowski M, Jarmoluk A. Effect of filmforming alginate/chitosan polyelectrolyte complex on the storage quality of pork. Molecules. 2017;22(1).

47.Kim JY, Jun JH, Kim SJ, Hwang KM, Choi SR, Han SD, et al. Wound healing efficacy of a chitosan-based film-forming gel containing tyrothricin in various rat wound models. Arch Pharm Res. 2015;38(2):229-38.

48. Alsarra IA. Chitosan topical gel formulation in the management of burn wounds. Int $\mathrm{J}$ Biol Macromol. 2009;45(1):16-21.

49. Hamedi H, Moradi S, Hudson SM, Tonelli AE. Chitosan based hydrogelsand their applications for drug delivery in wound dressings: A review. Carbohydr Polym [Internet]. 2018;199(June):445-60. Available from: 
50. Fundo JF, Galvis-Sanchez AC, Delgadillo I, Silva CLM, Quintas MAC. The Effect of Polymer/ Plasticiser Ratio in Film Forming Solutions on the Properties of Chitosan Films. Food Biophys. 2015;10(3):324-33.

$51 . Z i a n i \mathrm{~K}$, Oses J, Coma V, Maté Jl. Effect of the presence of glycerol and Tween 20 on the chemical and physical properties of films based on chitosan with different degree of deacetylation. LWT - Food Sci Technol. 2008;41(10):2159-65.

52. El Fray M, Niemczyk A, Pabin-Szafko B. Chemical modification of chitosan with fatty acids. Prog Chem Appl Chitin its Deriv. 2012;2012:29-36.

53. Yang Y, Sun C, Yip HL, Sun R, Wang X. Chitosan-Assisted Crystallization and Film Forming of Perovskite Crystals through Biomineralization. Chem - An Asian J. 2016;11(6):893-9. 